\title{
Drug Treatment
}

\section{Dosage Patterns in Methadone Treatment: Results from a National Survey, 1988-2005}

\author{
Harold A. Pollack and Thomas D'Aunno
}

Objective. To examine the extent to which U.S. methadone maintenance facilities meet established standards for minimum dosages, 1988-2005.

Data Source. Data were collected from a nationally representative sample of outpatient treatment facilities in $1988(n=172), 1990(n=140), 1995(n=116), 2000$ $(n=150)$, and $2005(n=146)$.

Study Design. Random-effects multiple regression analysis was used to examine unit characteristics associated with below recommended doses.

Data Collection. Data regarding the proportion of patients who received maintenance dosages of $<40,60$, and $80 \mathrm{mg} /$ day were collected from unit directors and clinical supervisors.

Principal Findings. Forty-four percent of patients receive doses of at least $80 \mathrm{mg}$ / day-the threshold identified as recommended practice in recent work. Thirty-four percent of patients receive doses below $60 \mathrm{mg}$ /day, while 17 percent receive doses below $40 \mathrm{mg} /$ day. Units that serve a high proportion of African American or Latino clients were more likely to report low-dose care. Units managed by individuals who strongly favor abstinence models (e.g., Narcotics Anonymous) were more likely to provide low-dose care.

Conclusions. One-third of methadone facilities provide doses below recommended levels. Managerial attitudes about abstinence and their relationship to low doses underscore the contested role of methadone in treatment of opiate disorders.

Key Words. Methadone maintenance, substance abuse treatment, opiate, managed care

How well do the nation's methadone-maintenance treatment facilities meet established standards for best-practice care? Prior research indicates that methadone treatment providers made marked progress in meeting one key care standard between 1988 and 2000: providing sufficient methadone dosage (D'Aunno and Pollack 2002). Nonetheless, national year 2000 data also indicate that 35 percent of all patients were receiving methadone doses of 
$60 \mathrm{mg}$ /day or less, levels below the minimum recommended doses (D'Aunno and Pollack 2002). Recent research indicates that methadone treatment is most effective at levels of $80 \mathrm{mg}$ /day (Strain et al. 1999), but in 2000, only 31 percent of patients received doses at this level.

\section{BACKGROUND}

Heroin use is associated with severe social and medical consequences for users and for others. In 2004, heroin use disorders accounted for 14 percent of admissions to substance abuse treatment services (SAMHSA 2006). Further, the majority of persistent heroin users are infected with hepatitis $\mathrm{C}$ virus, with especially high incidence among young users (Des Jarlais et al. 2003; Lorvick et al. 2001).

Moreover, opiate overdose results in an estimated mortality incidence of 1-2 percent/year among active injection drug users (Oppenheimer et al. 1994; Strang et al. 1996, 1999; Sporer 2003; Scott et al. 2007).

Methadone-maintenance therapy has been the primary treatment approach for heroin abuse in the United States for over 30 years. Methadone blocks heroin's narcotic effects without creating a drug "high," eliminates withdrawal symptoms, and relieves the craving associated with addiction. Methadone is administered orally in licensed clinics and its effects typically last 24-36 hours. A National Institutes of Health (NIH) Consensus Statement (1997) concluded, "Methadone maintenance treatment is effective in reducing illicit opiate drug use, in reducing crime, in enhancing social productivity, and in reducing the spread of viral diseases such as AIDS and hepatitis."

For safety reasons, a typical course of methadone treatment begins with dosages $<40 \mathrm{mg} /$ day. This dosage is then increased in increments no greater than $10 \mathrm{mg}$ twice a week until dependence-related opiate cravings are eliminated (Lowinson et al. 2004). Once this so-called maintenance level is reached, guidelines recommend that patients are offered additional medical and social services, including counseling, to address underlying causes and comorbidities linked to opiate use.

Reductions in methadone dose levels, if any, should occur only after several months in maintenance therapy and may take several weeks to achieve

Address correspondence to Harold A. Pollack, M.P.P., Ph.D., Associate Professor of Social Service Administration, Faculty Chair, Center for Health Administration Studies, University of Chicago, 969 East 60th St., Chicago, IL 60637; e-mail: haroldp@uchicago.edu. Thomas D’Aunno, Ph.D., is with INSEAD, Boulevard de Constance, 77305 Fontainebleau Cedex, France. 
(Lowinson et al. 2004). Indeed, some individuals may require quite prolonged maintenance therapy. In this view, heroin dependence is best viewed as a chronic condition similar to hypertension, which also requires an indefinite period of medication.

One potential confusion in methadone treatment arises from the need to individualize dose levels while ensuring therapeutic dose levels. On the one hand, methadone dosage should be determined individually because of differences in metabolism. On the other hand, results from key studies, summarized below, show that patients who take daily doses of methadone that exceed $80 \mathrm{mg} / \mathrm{day}$, and who maintain an average plasma concentration of about $400 \mathrm{ng} / \mathrm{mL}$, engage in relatively little illicit drug use and have better treatment outcomes.

In a large-scale field study of treatment effectiveness (the Drug Abuse Treatment Outcome Study, DATOS), Hubbard (1989) found that treatment duration is the most important predictor of posttreatment outcomes. Treatment outcomes improved the longer the patients stayed in treatment, and treatment duration $<19$ months was significantly less effective than longer treatment periods (see also, Sees et al. 2000).

In turn, results from the DATOS confirmed results from other key studies (e.g., Ball and Ross 1991), which showed that the most important predictor of treatment duration is methadone dose level. Results from a random-assignment clinical trial by Strain et al. (1999) underscored these findings. This study compared treatment outcomes between a group that received high-dose, $80-100 \mathrm{mg} /$ day, methadone treatment and a group receiving more moderate doses of $40-50 \mathrm{mg} /$ day.

Strain et al. (1999) evaluated these patients through the analysis of twiceweekly observed urine testing, weekly patient reports of heroin use, and the length of time patients remained in treatment. The high-dose group used a significantly lower mean quantity of opiates than did the moderate-dose group. Patients in the high-dose group reported using opiates no more than once a week. The moderate-dose group reported using drugs two to three times per week on average. There were no gender- or race-related differences in outcome across the two groups, and no difference was reported between the high- and moderate-dose patients for side effects such as grogginess or constipation.

Neither this study nor any other studies have found that the relationships among methadone dose levels, retention in treatment, and treatment outcomes are mitigated by the need to individualize dose levels. Although optimal dose levels may vary somewhat from one individual to another, there is 
no evidence that these variations should prevent clinics from providing average doses in the range of $80-100 \mathrm{mg} /$ day.

\section{Current Context of Methadone Treatment}

The policy context and marketplace for methadone treatment have changed recently. One major change occurred through federal legislation, which moved the regulation of methadone treatment facilities from the Drug Enforcement Agency to Substance Abuse and Mental Health Services Administration (SAMSHA; 2001). To improve the quality of care that methadone treatment facilities provide, the new legislation mandated that they receive accreditation; the Joint Commission on the Accreditation of Health Care Organizations (JCAHO) and the Commission on Accreditation of Recovery Facilities (CARF) now provide accreditation for methadone facilities. More generally, policy makers and researchers are focusing on increasing the extent to which substance abuse treatment providers meet empirically established standards of care (McGlynn et al. 2003), and the Institute of Medicine specifically cited deficiencies in treatment for opiate use as a cause for concern (IOM 2005).

Another prominent change is the growth of managed care as a payment mechanism for methadone treatment (SAMHSA 2004). Approximately 30 percent of methadone providers participate in some form of managed care. For these providers and their tens of thousands of patients, managed care has the potential to improve treatment, for example by improved linkage of patients to needed medical care. Yet, managed care may also hinder treatment by limiting treatment duration, a key factor in treatment effectiveness (Friedmann et al. 2006).

Finally, evidence suggests that some managers and staff members in methadone treatment facilities continue to hold attitudes inimical to high methadone doses (Caplehorn, Lumley, and Irwig 1998). Many treatment professionals, as well as important policy makers, express concern that methadone treatment "substitutes one addiction for another" (Caplehorn, Lumley, and Irwig 1998; Kleinfield 1999). Many individuals who hold this view also support treatment models that discourage or seek to limit medication-based approaches to address substance abuse problems. Followers of such models promote the idea that if methadone is to be used in treatment, it should be used as briefly and in as low a dosage as possible (Caplehorn, Lumley, and Irwig 1998). 
Such views reflect continuing cultural and clinical ambivalence regarding methadone provision and use. They run counter, however, to available clinical trial data and to repeated conclusions by expert consensus panels regarding clinical outcomes among patients in substance abuse treatment (Gerstein and Harwood 1990; Strain et al. 1999; NIH 2001). Available data from many studies indicate that sustained control of opiate disorders is most reliably achieved through high-dose regimens that may require many months of administration (NIH 2001).

\section{Research QUestions AND ANALYTIC APPROACH}

This paper addresses two questions. First, to what extent are the nation's methadone treatment units meeting empirically established standards of care for methadone dose level? Second, what characteristics of treatment units are associated with variation in their performance?

To address this second question, we draw on prior research, which indicates that variation in the methadone dose levels that units provide is related to variables in three key categories: (1) patient and staff characteristics; (2) units' ownership, payment (i.e., managed care arrangements), and accreditation; (3) managerial attitudes and beliefs about treatment and human immunodeficiency virus (HIV) prevention (D'Aunno and Vaughn 1992; D'Aunno and Pollack 2002; Pollack, D'Aunno, and Lamar 2006).

A particularly important finding is that units that treat higher percentages of African American patients are less likely to provide adequate methadone dose levels (D'Aunno and Pollack 2002). Thus, we examine units' percentage of African American and Hispanic patients.

Similarly, prior research indicates that unit accreditation and ownership are related to dose levels. Between 1988 and 2000, units that had JCAHO accreditation were more likely to provide adequate dose levels (D'Aunno and Pollack 2002). Because CARF now also accredits methadone treatment units, we examined both JCAHO and CARF accreditation.

In some prior analyses, publicly owned units were more likely to provide adequate methadone dose levels, perhaps because they are more closely tied to government research and regulatory bodies (e.g., the National Institute on Drug Abuse). In contrast, the relationship of managed care arrangements to methadone dose levels has not been examined in prior research, yet, as noted above, managed care has the potential to affect treatment practices in several ways. 
Finally, as noted above, prior studies indicate that many managers and staff members in methadone treatment units hold beliefs and values that run counter to best practices. Yet, no studies have examined the relationships of such attitudes, if any, to variation in methadone dose levels after controlling for the variables discussed above. Thus, examining managers' attitudes is an important new contribution of this paper.

We first present results from random effects models using national data from 1988 to 2005 . We then focus on the 2005 data to understand characteristics of treatment units that continue to administer low methadone dose levels.

\section{DATA AND METHODS}

This study uses data from a longitudinal, panel survey, the National Drug Abuse Treatment System Survey (NDATSS), conducted in 1988, 1990, 1995, 2000, and 2005, by the University of Michigan's Institute for Social Research. NDATSS, funded by the National Institute on Drug Abuse, examines the organizational structure, operating characteristics, and treatment practices of the nation's outpatient substance abuse treatment programs.

\section{Sampling Frame}

Following previous work, we define a methadone treatment unit as a physical facility with resources dedicated specifically to treating opiate dependence through methadone (D'Aunno and Pollack 2002). Methadone programs with multiple treatment units or sites were identified, and units were sampled randomly from such programs. The initial sampling frame consisted of the Food and Drug Administration's (FDA) 1988 list of U.S. methadone maintenance treatment units $(N=587)$.

The population of methadone treatment units changes due to the founding and closure of treatment units. We, therefore, augmented the original list in $1998(N=871)$. To identify later changes in the population, we used SAMSHA licensing records to find an additional 429 methadone treatment units. Because the FDA, and now SAMSHA, licenses all methadone providers, these lists precisely identify the entire U.S. population of approved methadone treatment units $(N=964$ in 2004) (SAMHSA 2004). We excluded units that provide detoxification services; the sample thus consists only of units that provide methadone-maintenance treatment. 


\section{Sample}

The response rate for each NDATSS wave exceeded 80 percent, varying from a low of 82 percent in 1988 to 92 percent in the year 2000 wave. We conducted analyses at each wave to determine whether participating units differed from nonparticipants; results showed no significant differences. Further, we added 47 new methadone units to the sample in 2000 to ensure that the 2000 cross section as a whole was representative of the population of methadone treatment units; the panel sample alone would not have represented these newer units. Analyses also showed that these new units did not differ from the panel units.

For the 2005 data collection, we contacted the 150 participating units from 2000, and of these, 112 were still operating and agreed to participate. Similar to our approach in 2000, we supplemented the panel sample with a sample of units that had been founded since 1998 to ensure that this cross section would represent the nation's methadone treatment units. Thirty-eight units were selected randomly from the list of 429 units that were identified as having been founded between 1998 and 2003, and of these, 34 agreed to participate, an 89 percent response rate. Thus, the total sample for 2005 is 146 units.

We conducted sensitivity analyses to determine whether nonparticipating units differed at baseline from participating units. We found that the two groups did not differ. Analyses also show that the results reported below do not differ between panel units and the 34 units that we added to the sample, indicating that recent observed changes in methadone dose levels between 2000 and 2005 are not due to the new units added to the NDATSS sample. ${ }^{1}$

\section{Data Collection, Reliability, and Validity}

The unit director and supervisor of clinical services of each participating unit completed telephone surveys. We followed established methods that previous research shows maximize data reliability and validity in telephone surveys (Adams and Heeringa 2001).

More specifically, each wave of the NDATSS involved several steps. Before each wave of the survey, we conducted case studies to inform survey development; pretested the survey twice with a national random sample of at least 40 units; provided extensive training about our study for telephone interviewers who have already been trained at the Institute for Social Research; and sent each unit director a cover letter explaining the 
study, along with work sheets that informed participants of the requested data and enabled them to consult financial and administrative records before the call.

During the survey, we guaranteed confidentiality and feedback reports to respondents, conducted in vivo checks on interviews, and used frequent probes and follow-up questions. We also conducted dozens of computer-assisted internal consistency checks of key numbers (e.g., numbers of clients) during interviews and, when necessary, either discussed problems with respondents immediately or called them back to address these problems.

After the data were collected, extensive reliability checks were performed within each survey. Typical reliability checks for data from an individual treatment unit included: comparisons of responses among related questions for consistency; comparisons of responses with data reported by the same treatment unit elsewhere; comparisons of responses on different protocols of the survey (i.e., unit director and clinical supervisor); and, for panel respondents, comparisons of responses over time.

We have conducted several studies of NDATSS data reliability and validity. One critical study compares data obtained in the 1990 NDATSS to data obtained from a 1990 national study of treatment units and clients conducted at Brandeis, i.e., the Drug Services Research Survey (DSRS) (Batten et al. 1993). Given the timing, samples and procedures of NDATSS and DSRS, one would expect a close correspondence to their data. This is what we find. For example (1) 1990 NDATSS data on treatment duration from 323 treatment units very closely match data from a national sample of 520 patientdischarge abstracts (taken from 52 treatment units; see Batten et al. 1993): NDATSS data show an average treatment duration of 6.1 months versus 5.9 months for the discharge record data, (2) NDATSS had a mean number of current clients in treatment of 100.3 versus 100.9 for DSRS, and (3) the number of paid treatment counselors was 8.2 in NDATSS and 8.2 in DSRS. Thus, results from this study show substantial support for the validity of our data.

Further, to evaluate the validity of NDATSS methadone dose data, we compared them with data obtained from two other national studies, DSRS (described above), and a study by Kleber et al. (2000) at Columbia University. These comparisons are important because the Brandeis and Columbia studies also used national samples of methadone treatment units and, in contrast to our study, they collected data on-site from patient records. These data strongly support the validity of the NDATSS data. 


\section{Variables}

Methadone Treatment Practices. Using data from clinical supervisors, we calculated the percentage of patients in each treatment unit who received dosages that were below 40,60 , or $80 \mathrm{mg} /$ day. These measures were calculated only for patients who had been receiving the same methadone dose for at least 2 weeks. They, therefore, measure the dose level that units dispense for patients whose dose levels have stabilized.

Patient Characteristics. Clinical supervisors reported two important characteristics of patient mix: employment status (percentage of patients who are currently unemployed) and race/ethnicity (percentage of African American and Hispanic/Latino patients). These measures are characteristic of the mix of patients at the unit level of analysis; we do not have data from individual patients.

Unit Characteristics. Directors reported unit ownership (public, private for profit, and private not-for-profit; we used public as the referent category), and we also used data from unit directors to measure JCAHO and CARF accreditation $(1=$ yes, $0=$ no).

Following D'Aunno and Vaughn $(1992,1995)$ we used data from clinical supervisors to measure the percentage of staff members who are ex-addicts. Further, using five-point Likert scales, clinical supervisors reported the extent to which they support the effectiveness of abstinence approaches to recovery $(1=$ no extent, $5=$ a very great extent). In a similar manner, unit directors were asked the extent that they oppose syringe exchange, the extent that they support the provision of HIV prevention information to injection drug users, and the extent that their OSAT unit includes staff who work specifically on HIV prevention $(1=$ no extent, $5=\mathrm{a}$ very great extent). For the latter variable, we characterize OSAT units as having limited staffing commitment to HIV prevention if they indicate "no extent" or "a limited extent" regarding the presence of staff dedicated to this task.

We examined the impact of managed care scope and stringency on dose levels. Following prior work (Lemak and Alexander 2001), we define managed care scope as the proportion of patients who were members of a health maintenance organization (HMO) or a preferred provider organization (PPO). In contrast, managed care stringency captures the 
proportion of clients requiring preauthorization of services. Clinical supervisors reported the percentage of clients who belong to HMO/PPOs and the percent of clients whose payment sources required authorization before clients could begin treatment. Finally, clinical supervisors reported the number of methadone clients in treatment.

Control for Geography and Trend Effects. We controlled for geographic location using a census division scale (northeast, midwest, south, and west), with the northeast serving as the referent category. To capture time effects, we created dummy variables corresponding to the year in which survey data were collected, with 2005 serving as the referent year.

\section{Data Analysis}

We use multivariate regression analysis to examine trends and correlates of methadone dosage policies. Because we collect multiple waves of data from the same treatment units, unobserved unit characteristics may influence our analyses. Units differ in client case mix and other factors. We capture many such factors in our multivariate model. However, important unit characteristics are unobserved-such as features of local drug markets. Because these unobserved characteristics are likely to be stable over time, and because we wish to examine the impact of observed characteristics such as client case mix and other factors, we use a random-effect regression specification (Hsiao 2003).

This random-effects specification relies on important econometric assumptions. Unobserved stable unit characteristics may be correlated with the observed independent variables we include in our models. For example, clients with specific (though unobserved) clinical indications requiring higher doses might congregate in public treatment facilities.

Because such patterns potentially induce bias, we scrutinize our regression specification using a Hausman test. In particular, we estimate a fixedeffect regression specification and examine whether the resulting point estimates statistically differ from our random-effect results (Hsiao 2003). The fixed-effect specification relates the variation within a given unit in observed methadone doses to observed within-unit variation in the independent variables. Under this conservative approach, fixed characteristics, such as region, which do not vary over time within a specific OSAT unit do not contribute to the estimation. 
If the random-effects model is correctly specified, the two approaches will yield consistent point estimates for all time-varying covariates. If point estimates from the two models yield statistically (and clinically) significant differences, unobserved heterogeneity may bias the random-effect coefficients.

\section{RESULTS}

Table 1 shows mean methadone dosages by year within the study sample. Here, we have weighted the data by unit size to capture the experience of the typical patient. Between 1988 and 2005, we observed large declines in the prevalence of low dosing. The proportion of patients who received doses below $60 \mathrm{mg} /$ day - the minimum recommended by the Institute of Medicine and by consensus panels-declined from 79.5 to 34.4 percent in this 17-year span. We observed a similar, though not as steep, decline in the proportion of patients receiving doses below $40 \mathrm{mg}$ /day: 44.8 percent in 1988 versus 17.1 percent in 2005.

We also found a rising proportion of patients receiving doses that exceed $80 \mathrm{mg} /$ day. By 2005 , approximately 44 percent of patients received at least $80 \mathrm{mg} /$ day, the range marked as most effective by Strain et al. 1999 .

Table 2 shows the results from random-effect regression models for our pooled sample of 1988-2005 survey waves. Consistent with prior findings, units with JCAHO accreditation are more likely to provide higher doses (D'Aunno, Folz-Murphy, and Lin 1999; D'Aunno and Pollack 2002). Also consistent with prior research, units that treat higher percentages of African Americans are more likely to provide low doses and less likely to provide higher doses. Units with higher percentages of Hispanic patients have the

Table 1: Mean Methadone Dosages by Year

\begin{tabular}{|c|c|c|c|}
\hline & $\begin{array}{l}\% \text { of Patients } \\
\text { below } 40 \mathrm{mg} / \text { day }\end{array}$ & $\begin{array}{l}\% \text { of Patients } \\
\text { below } 60 \mathrm{mg} / \text { day }\end{array}$ & $\begin{array}{c}\% \text { of Patients } \\
\text { below } 80 \mathrm{mg} / \mathrm{day} y\end{array}$ \\
\hline 1988 & 44.8 & 79.5 & 94.2 \\
\hline 1990 & 36.0 & 70.2 & 89.4 \\
\hline 1995 & 19.4 & 50.0 & 77.9 \\
\hline 2000 & 13.5 & 35.1 & 69.1 \\
\hline 2005 & 17.1 & 34.4 & 56.3 \\
\hline
\end{tabular}

Source: National Drug Abuse Treatment System Survey. 
Table 2: Model of Methadone Dosages by Year

\begin{tabular}{|c|c|c|c|}
\hline & $\begin{array}{c}\% \text { of Patients below } \\
40 \mathrm{mg} / \text { day } \\
\text { (Asymptotic Z-Ratio) }\end{array}$ & $\begin{array}{c}\% \text { of Patients below } \\
60 \mathrm{mg} / \text { day } \\
\text { (Asymptotic Z-Ratio) }\end{array}$ & $\begin{array}{c}\% \text { of Patients below } \\
80 \mathrm{mg} / \text { day } \\
\text { (Asymptotic Z-Ratio) }\end{array}$ \\
\hline \multicolumn{4}{|l|}{ Time trends } \\
\hline 1988 & $\begin{array}{l}29.891 \\
(9.38)^{* * * *}\end{array}$ & $\begin{array}{l}49.139 \\
(14.19) * *\end{array}$ & $\begin{array}{l}38.509 \\
(12.76) * *\end{array}$ \\
\hline 1990 & $\begin{array}{l}21.611 \\
(6.44) * * *\end{array}$ & $\begin{array}{l}40.744 \\
(11.22)^{* * * *}\end{array}$ & $\begin{array}{l}34.456 \\
(10.99)^{* * * *}\end{array}$ \\
\hline 1995 & $\begin{array}{c}6.908 \\
(2.29)^{*}\end{array}$ & $\begin{array}{l}21.870 \\
(6.66)^{* * *}\end{array}$ & $\begin{array}{l}24.918 \\
(8.76)^{* * * *}\end{array}$ \\
\hline $1999 / 2000$ & $\begin{array}{c}0.938 \\
(0.340)\end{array}$ & $\begin{array}{l}7.152 \\
(2.39)^{*}\end{array}$ & $\begin{array}{l}15.320 \\
(5.93)^{* * *}\end{array}$ \\
\hline 2005 & Referent & Referent & Referent \\
\hline \multicolumn{4}{|l|}{ Client/staff characteristics } \\
\hline$\%$ African American & $\begin{array}{l}0.131 \\
(3.21) * *\end{array}$ & $\begin{array}{l}0.249 \\
(5.34)^{* * *}\end{array}$ & $\begin{array}{l}0.268 \\
(5.99)^{* * *}\end{array}$ \\
\hline$\%$ Hispanic & $\begin{array}{l}0.098 \\
(2.19)^{*}\end{array}$ & $\begin{array}{l}0.116 \\
(2.24)^{*}\end{array}$ & $\begin{array}{l}0.115 \\
(2.25)^{*}\end{array}$ \\
\hline$\%$ of clients who are unemployed & $\begin{array}{r}-0.022 \\
(0.600)\end{array}$ & $\begin{array}{r}-0.039 \\
(0.950)\end{array}$ & $\begin{array}{r}-0.066 \\
(1.820)\end{array}$ \\
\hline$\%$ of staff who are ex-addicts & $\begin{array}{c}0.036 \\
(1.060)\end{array}$ & $\begin{array}{c}0.022 \\
(0.570)\end{array}$ & $\begin{array}{c}0.023 \\
(0.690)\end{array}$ \\
\hline $\begin{array}{l}\text { Current number of methadone } \\
\text { clients }\end{array}$ & $\begin{array}{c}-0.001 \\
(0.650)\end{array}$ & $\begin{array}{c}0.001 \\
(0.440)\end{array}$ & $\begin{array}{c}0.000 \\
(0.260)\end{array}$ \\
\hline \multicolumn{4}{|l|}{ Ownership status } \\
\hline Private for-profit & $\begin{array}{c}1.174 \\
(0.410)\end{array}$ & $\begin{array}{c}1.243 \\
(0.380)\end{array}$ & $\begin{array}{r}-2.740 \\
(0.870)\end{array}$ \\
\hline Private nonprofit & $\begin{array}{c}0.811 \\
(0.400)\end{array}$ & $\begin{array}{c}0.090 \\
(0.040)\end{array}$ & $\begin{array}{r}-0.743 \\
(0.320)\end{array}$ \\
\hline Public & Referent & Referent & Referent \\
\hline \multicolumn{4}{|l|}{ Accreditation } \\
\hline $\begin{array}{l}\text { Joint Commission on the } \\
\text { Accreditation of Health Care } \\
\text { Organizations (JCAHO) }\end{array}$ & $\begin{array}{r}-2.848 \\
(1.390)\end{array}$ & $\begin{array}{r}-4.079 \\
(1.760)\end{array}$ & $\begin{array}{r}-4.643 \\
(2.16)^{*}\end{array}$ \\
\hline $\begin{array}{l}\text { Commission on Accreditation of } \\
\text { Recovery Facilities (CARF) }\end{array}$ & $\begin{array}{r}-2.179 \\
(0.710)\end{array}$ & $\begin{array}{c}0.513 \\
(0.150)\end{array}$ & $\begin{array}{r}-2.178 \\
(0.730)\end{array}$ \\
\hline \multicolumn{4}{|l|}{ Region } \\
\hline Midwest & $\begin{array}{c}3.750 \\
(1.500)\end{array}$ & $\begin{array}{c}1.790 \\
(0.610)\end{array}$ & $\begin{array}{c}0.408 \\
(0.130)\end{array}$ \\
\hline South & $\begin{array}{c}1.849 \\
(0.720)\end{array}$ & $\begin{array}{c}-1.001 \\
(0.330)\end{array}$ & $\begin{array}{c}-4.764 \\
(1.530)\end{array}$ \\
\hline West & $\begin{array}{c}-2.751 \\
(1.020)\end{array}$ & $\begin{array}{c}0.017 \\
(0.010)\end{array}$ & $\begin{array}{c}2.294 \\
(0.690)\end{array}$ \\
\hline Northeast & Referent & Referent & Referent \\
\hline
\end{tabular}

continued 
Table 2. Continued

\begin{tabular}{|c|c|c|c|}
\hline & $\begin{array}{c}\% \text { of Patients below } \\
40 \mathrm{mg} / \text { day } \\
\text { (Asymptotic Z-Ratio) }\end{array}$ & $\begin{array}{c}\% \text { of Patients below } \\
60 \mathrm{mg} / \text { day } \\
\text { (Asymptotic Z-Ratio) }\end{array}$ & $\begin{array}{c}\% \text { of Patients below } \\
80 \mathrm{mg} / \text { day } \\
\text { (Asymptotic Z-Ratio) }\end{array}$ \\
\hline \multicolumn{4}{|l|}{ Managed care } \\
\hline$\%$ of clients in $\mathrm{HMO} / \mathrm{PPO}$ & $\begin{array}{c}0.002 \\
(0.190)\end{array}$ & $\begin{array}{r}-0.001 \\
(0.040)\end{array}$ & $\begin{array}{c}0.001 \\
(0.110)\end{array}$ \\
\hline $\begin{array}{l}\% \text { of clients requiring prior } \\
\text { authorization of services }\end{array}$ & $\begin{array}{l}0.099 \\
(2.61)^{* * *}\end{array}$ & $\begin{array}{c}0.085 \\
(1.98)^{*}\end{array}$ & $\begin{array}{r}0.017 \\
-0.420\end{array}$ \\
\hline \multicolumn{4}{|l|}{ Harm reduction/HIV prevention } \\
\hline $\begin{array}{l}\text { Director opposes syringe } \\
\text { exchange }\end{array}$ & $\begin{array}{c}2.050 \\
(1.220)\end{array}$ & $\begin{array}{c}1.933 \\
(1.040)\end{array}$ & $\begin{array}{c}1.761 \\
(1.070)\end{array}$ \\
\hline $\begin{array}{l}\text { Supervisor supports AA } \\
\text { effectiveness }\end{array}$ & $\begin{array}{c}2.718 \\
(1.660)\end{array}$ & $\begin{array}{c}2.654 \\
(1.470)\end{array}$ & $\begin{array}{c}3.231 \\
(2.00)^{*}\end{array}$ \\
\hline $\begin{array}{l}\text { Director supports information to } \\
\text { IDU regarding HIV prevention }\end{array}$ & $\begin{array}{r}-1.016 \\
(0.640)\end{array}$ & $\begin{array}{r}-3.960 \\
(2.30)^{*}\end{array}$ & $\begin{array}{r}-2.075 \\
(1.370)\end{array}$ \\
\hline $\begin{array}{l}\text { Limited staff dedicated to HIV } \\
\text { prevention }\end{array}$ & $\begin{array}{c}2.687 \\
(1.510)\end{array}$ & $\begin{array}{c}3.132 \\
(1.600)\end{array}$ & $\begin{array}{c}5.511 \\
(3.15)^{* * *}\end{array}$ \\
\hline $\begin{array}{l}\text { Hausman significance test } \\
\text { comparison of random-effect and } \\
\text { fixed-effect specifications }\end{array}$ & $p<.204$ & $p<.208$ & $p<.170$ \\
\hline $\begin{array}{l}\text { Joint significance: harm reduction/ } \\
\text { HIV prevention variables }\end{array}$ & $p<.148$ & $p<.021 *$ & $p<.002$ \\
\hline
\end{tabular}

Source: National Drug Abuse Treatment System Survey.

$* p<.05$.

$* * p<.01$.

$* * * * 0.001$.

HMO, health maintenance organization; HIV, human immunodeficiency virus; PPO, preferred provider organization; AA, Alcoholics Anonymous; IDU, injection drug users.

same dosing pattern as units with higher percentages of African American patients.

Managed care stringency (though not scope) was also correlated with low dose levels. Units whose participation in managed care arrangements requires patients to have preauthorization for treatment are less likely to provide dose levels above $60 \mathrm{mg} /$ day or above $40 \mathrm{mg}$ /day. Units that support or provide HIV prevention services are more likely to provide higher methadone doses and less likely to provide low doses. Given the four correlated variables in this domain, which all yield point estimates in the expected direction, we employed a joint significance test. In our pooled sample, a $\chi^{2}$ test for joint significance of the four variables that measure unit support for abstinence versus harm reduction models shows that units that support the latter are significantly more likely to provide higher dose levels $(>60$ and $80 \mathrm{mg} /$ day). 
We performed Hausman tests for all specifications. Differences between fixed-effect and random-effect coefficients were statistically insignificant in all three of our regression specifications, and generally supported the internal consistency of the random-effects model. However, point estimates for specific coefficients sometimes differed between the two specifications.

Point estimates for race/ethnicity were markedly larger in the randomeffects than in the fixed-effect specifications. This pattern suggests that units that treat larger percentages of nonwhite patients are more likely to have unobserved characteristics associated with low doses. We found a less pronounced but similar pattern for prior authorization, suggesting that units that accept such arrangements may have other important, unobserved differences from other methadone treatment units.

\section{Results}

Because current variations in methadone dose practices are most important for public policy and efforts to improve treatment practices, we also examined the 2005 data in cross section. Table 3 shows these results.

In one respect, we find a different pattern in the 2005 data from those observed in previous NDATSS survey waves. In the 2000 data, JCAHO accreditation was strongly correlated with methadone dose levels. JCAHOaccredited units were also 12 percentage points more likely to adhere to the recommended $60 \mathrm{mg} /$ day minimum dosage guideline, and were significantly more likely to provide doses exceeding $80 \mathrm{mg} /$ day. The coefficient on JCAHO accreditation declined markedly by the 2005 wave, and was no longer statistically significant.

Consistent with our panel analysis of all survey waves, we continued to find that the percentage of a unit's clients who are from racial and ethnic minority groups was strongly correlated with methadone-dosing practices. For every 1.0 percentage-point increase in the proportion of African American patients, we find a 0.15 percentage-point increase in the proportion of clients who receive $<40 \mathrm{mg} /$ day, a 0.33 percentage-point increase in the proportion of clients receiving $<60 \mathrm{mg} /$ day, and a 0.55 percentage-point increase in the proportion of clients receiving $<80 \mathrm{mg} /$ day in our most recent data. These differences are large and statistically significant. We found less stark results when we examined the percentage of Hispanic/Latino clients. Yet units that have larger percentages of Hispanic clients, too, were significantly more likely to provide doses of $<80 \mathrm{mg} /$ day. 
Table 3: Model of Methadone Dosages 2005

\begin{tabular}{|c|c|c|c|}
\hline & $\begin{array}{c}\% \text { of Patients below } \\
40 \mathrm{mg} / \text { day } \\
\text { (Asymptotic Z-Ratio) }\end{array}$ & $\begin{array}{c}\% \text { of Patients below } \\
60 \mathrm{mg} / \text { day } \\
\text { (Asymptotic Z- } \\
\text { Ratio) }\end{array}$ & $\begin{array}{c}\% \text { of Patients below } \\
\text { 80 mg/day } \\
\text { (Asymptotic Z- } \\
\text { Ratio) }\end{array}$ \\
\hline \multicolumn{4}{|l|}{ Client/staff characteristics } \\
\hline$\%$ African American & $\begin{array}{l}0.146 \\
(2.72)^{* * *}\end{array}$ & $\begin{array}{l}0.333 \\
(3.42)^{* * *}\end{array}$ & $\begin{array}{l}0.548 \\
(4.91)^{* * *}\end{array}$ \\
\hline$\%$ Hispanic & $\begin{array}{l}0.056 \\
(1.01)\end{array}$ & $\begin{array}{l}0.197 \\
(1.97)^{*}\end{array}$ & $\begin{array}{l}0.307 \\
(2.70)^{* * *}\end{array}$ \\
\hline$\%$ of clients who are unemployed & $\begin{array}{c}-0.118 \\
(2.01)^{*}\end{array}$ & $\begin{array}{c}-0.163 \\
(1.53)\end{array}$ & $\begin{array}{c}-0.148 \\
(1.21)\end{array}$ \\
\hline$\%$ of staff who are ex-addicts & $\begin{array}{c}-0.039 \\
(0.76)\end{array}$ & $\begin{array}{c}-0.095 \\
(1.03)\end{array}$ & $\begin{array}{c}-0.168 \\
(1.59)\end{array}$ \\
\hline $\begin{array}{l}\text { Current number of methadone } \\
\text { clients }\end{array}$ & $\begin{array}{c}0.003 \\
(2.12)^{*}\end{array}$ & $\begin{array}{c}0.002 \\
(1.08)\end{array}$ & $\begin{array}{c}0.001 \\
(0.51)\end{array}$ \\
\hline \multicolumn{4}{|l|}{ Ownership status } \\
\hline Private for-profit & $\begin{array}{c}-0.921 \\
(0.26)\end{array}$ & $\begin{array}{r}-1.161 \\
(0.18)\end{array}$ & $\begin{array}{c}-0.914 \\
(0.13)\end{array}$ \\
\hline Private nonprofit & $\begin{array}{l}0.875 \\
(0.25)\end{array}$ & $\begin{array}{c}-6.512 \\
(1.04)\end{array}$ & $\begin{array}{r}-5.201 \\
(0.73)\end{array}$ \\
\hline Public & Referent & Referent & Referent \\
\hline \multicolumn{4}{|l|}{ Accreditation } \\
\hline $\begin{array}{l}\text { Joint Commission on the } \\
\text { Accreditation of Health Care } \\
\text { Organizations (JCAHO) }\end{array}$ & $\begin{array}{c}-2.469 \\
(0.61)\end{array}$ & $\begin{array}{c}-0.872 \\
(0.12)\end{array}$ & $\begin{array}{r}-1.95 \\
(0.23)\end{array}$ \\
\hline $\begin{array}{l}\text { Commission on Accreditation of } \\
\text { Recovery Facilities (CARF) }\end{array}$ & $\begin{array}{r}-2.057 \\
(0.56)\end{array}$ & $\begin{array}{c}0.411 \\
(0.06)\end{array}$ & $\begin{array}{r}-2.71 \\
(0.35)\end{array}$ \\
\hline \multicolumn{4}{|l|}{ Region } \\
\hline Midwest & $\begin{array}{c}-1.923 \\
(0.58)\end{array}$ & $\begin{array}{l}2.843 \\
(0.46)\end{array}$ & $\begin{array}{l}7.704 \\
(1.07)\end{array}$ \\
\hline South & $\begin{array}{r}-3.08 \\
(0.90)\end{array}$ & $\begin{array}{c}-7.395 \\
(1.19)\end{array}$ & $\begin{array}{c}-6.394 \\
(0.90)\end{array}$ \\
\hline West & $\begin{array}{c}2.488 \\
(0.76)\end{array}$ & $\begin{array}{l}4.011 \\
(0.68)\end{array}$ & $\begin{array}{l}2.352 \\
(0.35)\end{array}$ \\
\hline Northeast & Referent & Referent & Referent \\
\hline \multicolumn{4}{|l|}{ Managed care } \\
\hline$\%$ of clients in $\mathrm{HMO} / \mathrm{PPO}$ & $\begin{array}{l}0.036 \\
(0.64)\end{array}$ & $\begin{array}{l}0.072 \\
(0.71)\end{array}$ & $\begin{array}{c}-0.049 \\
(0.42)\end{array}$ \\
\hline $\begin{array}{l}\% \text { of clients requiring prior } \\
\text { authorization of services }\end{array}$ & $\begin{array}{c}0.083 \\
(1.73)\end{array}$ & $\begin{array}{l}0.202 \\
(2.34)^{*}\end{array}$ & $\begin{array}{c}0.257 \\
(2.60) *\end{array}$ \\
\hline \multicolumn{4}{|l|}{ Harm reduction/HIV prevention } \\
\hline $\begin{array}{l}\text { Director opposes syringe } \\
\text { exchange }\end{array}$ & $\begin{array}{c}0.301 \\
(0.12)\end{array}$ & $\begin{array}{l}3.272 \\
(0.71)\end{array}$ & $\begin{array}{l}8.454 \\
(1.60)\end{array}$ \\
\hline $\begin{array}{l}\text { Supervisor supports AA } \\
\text { effectiveness }\end{array}$ & $\begin{array}{l}3.585 \\
(1.36)\end{array}$ & $\begin{array}{c}8.786 \\
(1.84)\end{array}$ & $\begin{array}{l}9.012 \\
(1.65)\end{array}$ \\
\hline
\end{tabular}


Table 3. Continued

\begin{tabular}{|c|c|c|c|}
\hline & $\begin{array}{c}\% \text { of Patients below } \\
40 \mathrm{mg} / \text { day } \\
\text { (Asymptotic Z-Ratio) }\end{array}$ & $\begin{array}{c}\% \text { of Patients below } \\
60 \mathrm{mg} / \text { day } \\
\text { (Asymptotic Z- } \\
\text { Ratio) }\end{array}$ & $\begin{array}{c}\% \text { of Patients below } \\
\text { 80 mg/day } \\
\text { (Asymptotic Z- } \\
\text { Ratio) }\end{array}$ \\
\hline $\begin{array}{l}\text { Director supports information to } \\
\text { IDU regarding HIV prevention }\end{array}$ & $\begin{array}{c}-1.234 \\
(0.52)\end{array}$ & $\begin{array}{c}-6.684 \\
(1.56)\end{array}$ & $\begin{array}{c}-9.305 \\
(1.89)\end{array}$ \\
\hline $\begin{array}{l}\text { Limited staff dedicated to HIV } \\
\text { prevention }\end{array}$ & $\begin{array}{c}-1.644 \\
(0.62)\end{array}$ & $\begin{array}{c}-0.866 \\
(0.18)\end{array}$ & $\begin{array}{r}1.227 \\
(0.22)\end{array}$ \\
\hline $\begin{array}{l}\text { Joint significance: harm reduction/ } \\
\text { HIV prevention variables }\end{array}$ & $p<.58$ & $p<.147$ & $p<.04^{*}$ \\
\hline
\end{tabular}

Source: National Drug Abuse Treatment System Survey.

$* p<.05$.

$* * p<0.01$.

$* * * * 0.001$.

HMO, health maintenance organization; HIV, human immunodeficiency virus; PPO, preferred provider organization.

Further, the relationship between managed care stringency (requiring preauthorization of services) was stronger in 2005 than in earlier waves. For two of the three examined dose levels, 60 and $80 \mathrm{mg} /$ day, we found that managed care stringency was significantly associated with lower methadone doses. We found similar point estimates, although only marginally significant, for the lowest threshold of $40 \mathrm{mg} /$ day.

Similar to the results reported for all waves, the attitudes and behaviors with respect to abstinence and harm reduction are related to methadone dosing, although our results reach statistical significance only for the $80 \mathrm{mg} /$ day dosing level. Given the relatively small sample size, we lacked the statistical power to interact these main effects with survey wave. In exploratory regressions, we did find significant results for our $80 \mathrm{mg}$ /day threshold. For this outcome, opposition to syringe exchange and support for abstinence-based approaches were more important predictors in 2004/2005 than in previous NDATSS waves. This finding suggests that as the importance of methadone dosing became more widely known within the profession, staff attitudes became more important determinants of dosing practices.

\section{DISCUSSION}

The period 1988-2005 marked a sharp reduction in methadone "under-dosing" practices among methadone-treatment units. Nonetheless, in 2005 only 
44 percent of methadone patients in surveyed treatment units received doses of at least $80 \mathrm{mg} /$ day - the threshold identified as recommended practice in recent work. Further, the NDATSS survey data show that between 2000 and 2005 the proportion of patients who received below $40 \mathrm{mg} /$ day actually increased, though not significantly, from 13.5 to 17.1 percent.

We find other noteworthy differences from earlier results. JCAHO accreditation - an important variable in our prior analyses of 1988-2000 datawas much less important in the year 2005 data. Perhaps JCAHO accreditation is less important as a predictor of high methadone doses in 2005 because, as noted above, accreditation became mandated after 2000. As a result, methadone-treatment units that sought JCAHO accreditation before 2000 may differ substantially from units that only more recently were required to have either JCAHO or CARF accreditation. Specifically, it is possible that, compared with other units, the earlier wave of JCAHO-accredited units were more motivated to improve quality of care and were relatively resource-rich (e.g., in funds, staff, and training). These factors, either singly or in combination, may have enabled JCAHO-accredited units to be technology leaders that responded earlier to research documenting the benefits of high methadone doses.

The continuing strong tie between the proportion of a unit's patients who are from racial minority groups and methadone dose remains a concern. Units that treat a high percentage of African American patients are much more likely than units that treat a higher percentage of non-Hispanic whites to provide doses below recommended levels. Controlling for other factors in our most recent wave, each percentage-point increase in the proportion of African American clients was correlated with a 0.33 percentage-point increase in the proportion of patients receiving $<60 \mathrm{mg}$ /day, and with an even larger increase in the proportion of patients receiving $<80 \mathrm{mg} /$ day. This effect was large and statistically significant, and showed little decline from the results documented in earlier NDATSS survey waves.

Our differing point estimates in fixed-effect and random-effect specifications provides some evidence that nonwhite clients sort (or are sorted) into low-dosage units. We know of no clinical studies that demonstrate that nonwhite methadone patients systematically prefer or achieve better outcomes on low-dose treatment. Rather, it is more likely that common underlying weaknesses in treatment units are at work in our results. Units that provide low doses may lack human and financial resources (well-trained, well-paid, and stable work forces) or management systems (information systems; quality of care indicators and systematic checks of these) that contribute to their inability to meet care standards. 
Examining this explanation should be a priority, especially in studies that are not limited-as ours is - by a lack of patient-level data. As noted, investigators have validated NDATSS data in several ways to ensure that our unit-level data are consistent with surveys of individual patient-level data. We cannot explore within-unit variation in service delivery or outcomes that may be correlated with patient-level variables. We also lack direct, patient-level measures of treatment outcomes.

We also find that managed care stringency is associated with lower methadone doses. Unit staff may be reluctant to provide high methadone doses to patients covered by managed care contracts simply because such a higher-dose course of treatment requires more time, and managed care shortens treatment duration. Indeed, there is evidence to support the link between higher methadone doses and longer treatment duration (e.g., Hubbard et al. 1989) and between managed care and shorter treatment duration (Lemak and Alexander 2001).

Finally, we are struck by the connection between managerial attitudes and methadone dose levels. Especially in our pooled sample, managers who support an abstinence orientation, who do not participate in HIV-prevention efforts, or who oppose syringe exchange are more likely to be in units that also provide low doses. After three decades of experience, basic differences and ambivalence about the proper goals of treatment continue to influence clinical practice, underscoring the contested role of methadone treatment for opiate disorders.

\section{ACKNOWLEDGMENTS}

Joint Acknowledgement/Disclosure Statement: Preparation of the manuscript was facilitated by Grant 5-R01-DA-3272-18 from the National Institute on Drug Abuse, Rockville, MD, and by a seed grant from the Chicago Center of Excellence in Health Promotion Economics, Chicago, IL.

Disclosures: None.

\section{NOTE}

1. We also conducted sensitivity analysis to examine the importance of right and left censoring of our dependent variables (confined to take values between 0 and 100 percent of clients). Interval regression specifications yielded quite similar point estimates, with slightly greater statistical significance for our key results. 


\section{REFERENCES}

Adams, T., and S. Heeringa. 2001. Outpatient Substance Abuse Treatment System Survey: Technical Documentation for OSATSS-5, 1999-2000. Ann Arbor, MI: Institute for Social Research.

Ball, J. C., and A. Ross. 1991. The Effectiveness of Methadone Maintenance Treatment. New York: Springer-Verlag.

Batten, H. L., C. M. Horgan, J. M. Prottas, L.J. Simon, M. J. Larson, E. A. Elliott, M. L. Bowden, and M. T. Lee. 1993. Drug Services Research Study, Phase I Final Report: Non-correctional Facilities. Waltham, MA: Institute for Health Policy, Brandeis University.

Caplehorn, J., T. Lumley, and L. Irwig. 1998. "Staff Attitudes and Retention of Patients in Methadone Maintenance Programs." Drug and Alcohol Dependence 52 (1): $57-61$.

D’Aunno, T., N. Folz-Murphy, and X. Lin. 1999. "Changes in Methadone Treatment Practices: Results from a Panel Study, 1988-1995.” American Journal of Drug and Alcohol Abuse 25 (4): 681-99.

D’Aunno, T., and H. Pollack. 2002. "Changes in Methadone Treatment Practices: Results from a National Panel Study, 1988-2000." Journal of the American Medical Association 288 (7): 850-6.

D'Aunno, T., and T. Vaughn. 1992. "Variations in Methadone Treatment Practices: Results from a National Study." Journal of the American Medical Association 267 (2): 253-8.

- 1995. "An Organizational Analysis of Service Patterns in Outpatient Drug Abuse Treatment Units." Journal of Substance Abuse Treatment 7 (1): 27-42.

Des Jarlais, D., T. Diaz, T. Perlis, D. Vlahov, C. Maslow, M. Latka, R. Rockwell, V. Edwards, S. R. Friedman, E. Monterroso, I. Williams, and R. S. Garfein. 2003. "Variability in the Incidence of Human Immunodeficiency Virus, Hepatitis B Virus, and Hepatitis C Virus Infection among Young Injecting Drug Users in New York City." American Journal of Epidemiology 157 (5): 467-71.

Friedmann, P., J. Alexander, Y. Yey, T. Nahra, S. Soliman, and H. Pollack. 2006. "Duration of Nonmethadone Outpatient Treatment: Results from a National Survey." Substance Abuse 27 (3): 47-53.

Gerstein, D. R., and H. J. Harwood. 1990. Treating Drug Problems. Washington, DC: National Academy Press, Institute of Medicine.

Hsiao, C. 2003. Analysis of Panel Data, 2d Edition. Cambridge, UK: Cambridge University Press.

Hubbard, R. L. 1989. Drug Abuse Treatment: A National Study of Effectiveness. Chapel Hill, NC: University of North Carolina Press.

IOM. 2005. Crossing the Quality Chasm: Adaptation to Mental Health and Addictive Disorders. Washington, DC: National Academy Press.

Kleber, H. 2000. "The National Evaluation of Substance Abuse Treatment Study." Paper Presented at the College on Studies of Drug Dependence, 62nd Annual Meeting, San Juan, Puerto Rico. 
Kleinfield, N. 1999. “On Permanent Parole: Days on Methadone, Bound by Its Lifeline." New York Times, January 2, p. A1.

Lemak, C., and J. Alexander. 2001. "Managed Care and Outpatient Substance Abuse Treatment Intensity." Journal of Behavioral Health Services and Research 28 (1): $12-29$.

Lorvick, J., A. Kral, K. Seal, L. Gee, and B. Edlin. 2001. "Prevalence and Duration of Hepatitis C among Injection Drug Users in San Francisco, CA.” American Journal of Public Health 91 (1): 46-7.

Lowinson, J. H., P. Ruiz, R. B. Millman, and J. G. Langrod. 2004. Substance Abuse: A Comprehensive Textbook, 4th Edition. Philadelphia: Lippincott Williams \& Wilkins.

McGlynn, E., S. Asch, J. Adams, J. Keesey, J. Hicks, A. DeCrisofaro, and E.A. Kerr. 2003. "The Quality of Care Delivered to Adults in the United States." New England Journal of Medicine 348 (26): 2635-45.

NIH. 2001. "Consensus Statement 108: Effective Medical Treatment of Opiate Addiction" [accessed on June 15, 2006]. Available at http://consensus.nih.gov/ 1997/1998TreatOpiateAddiction 108html.htm

Oppenheimer, E., C. Tobutt, C. Taylor, and T. Andrew. 1994. "Death and Survival in a Cohort of Heroin Addicts from London Clinics: A 22-Year Follow-Up Study." Addiction 89 (10): 1299-308.

Pollack, H., T. D'Aunno, and B. Lamar. 2006. “Outpatient Substance Abuse Treatment and HIV Prevention: An Update.” Journal of Substance Abuse Treatment 30 (1): 39-47.

SAMHSA. 2001. Opioid Drugs in Maintenance and Detoxification Treatment of Opiate Addiction. Part II. 42 CFR Part 8, January 17.

SAMHSA. 2004. "National Survey of Substance Abuse Treatment Services, 2004" [accessed on September 10, 2006]. Available at http://www.dasis.samhsa.gov/ webt/state/data/us04.pdf

SAMHSA. 2006. "Treatment Episode Data Set (TEDS)" [accessed on June 15, 2006]. Available at http://wwwdasis.samhsa.gov/teds04/tedshigh2k4.pdf

Scott, G., S. Thomas, H. Pollack, and B. Ray. 2007. "Observed Patterns of Illicit Opiate Overdose Deaths in Chicago, 1999-2003." Journal of Urban Health 84 (2): 292-306.

Sees, K. L., K. L. Delucchi, C. Masson, A. Rosen, H. W. Clark, H. Robillard, P. Banys, and S. M. Hall. 2000. "Methadone Maintenance for Opioid Dependence." Journal of the American Medical Association 284 (6): 694-5.

Sporer, K. 2003. "Strategies for Preventing Heroin Overdose.” British Medical Journal 326 (7386): 442-4.

Strain, E., G. Bigelow, I. Liebson, and M. Stitzer. 1999. "Moderate- vs High-Dose Methadone in the Treatment of Opioid Dependence: A Randomized Trial." Journal of the American Medical Association 281 (11): 1000-5.

Strang, J., S. Darke, W. Hall, M. Farrell, and R. Ali. 1996. "Heroin Overdose: The Case for Take-Home Naloxone." British Medical Journal 312 (7044): 1435-6. 
Strang, J., B. Powis, D. Best, L. Vingoe, P. Griffiths, C. Taylor, S. Welch, and M. Gossop. 1999. "Preventing Opiate Overdose Fatalities with Take-Home Naloxone: Pre-Launch Study of Possible Impact and Acceptability." Addiction 94 (2): 199-204.

\section{SUPPLEMENTARY MATERIAL}

The following supplementary material for this article is available online:

Appendix SA1: Author matrix.

Table S1: National Drug Abuse Treatment System Survey (NDATSS) Comparison with Drug Services Research Survey* (DSRS)(1990).

Table S2: Comparisons of Methadone Dose Levels in the Drug Services Research Study (DSRS), the National Evaluation of Substance Abuse Treatment Study* (NESAT), and National Drug Abuse Treatment System Survey (NDATSS).

This material is available as part of the online article from http:// www.blackwell-synergy.com/doi/abs/10.1111/j.1475-6773.2008.00870.x (this link will take you to the article abstract).

Please note: Blackwell Publishing is not responsible for the content or functionality of any supplementary materials supplied by the authors. Any queries (other than missing material) should be directed to the corresponding author for the article. 